\title{
"The Spirit in Prison": An Exegetical and Theological Study of 1 Peter 3:19
}

\author{
Ikechi Chidi Ekpendu, Ph.D \\ Department of Religious Studies, Babcock University Ilishan Remo, Ogun State
}

\begin{abstract}
The Phrase "the spirit in Prison" in 1 Peter 3:19 has generated confusion and misunderstanding in the right interpretation of the phrase among scholars. Some translate this phrase to mean disembodied souls that Jesus Christ preached to at His death, others see it as fallen angels and or demons. Against the above, this paper employed historical grammatical method of exegesis to ascertain the meaning of this phrase considering its content and context. It was discovered from the inquiry that the phrase means "people in darkness" with its implications on the theology of: suffering and Justification, death and resurrection, sin, grace, baptism and ascension of Christians.

DOI: $10.7176 /$ RHSS/9-12-04
\end{abstract}

Publication date:June $30^{\text {th }} 2019$

\section{Introduction}

The first epistle of Peter was written at a time when the Gentile converts were undergoing persecution. However, scholars agree that the major theme in that epistle is suffering. Thus Peter wrote his first epistle so as to strengthen and mold their conviction in the Christian faith (Torance and Torance, 1963). In fact, he informs his audience that while they are persecuted unjustly, they should rather regard such as the testing and trial of their faith, and once they hold on to the very end; it shall lead to the salvation of their souls. Further, Peter reminds his readers about the divine nature and purpose behind their calling. Thence he calls them to live a holy life befitting their election into the family of God. Beyond that, Peter emphasizes the relationship between the state and the church; and also the relationship between Christian servants and their masters. Moreover, First Peter hints on the fashion in which the Christian women dressed, that they may witness Christ even in their appearance. Therefore, First Peter covers virtually every aspect of life: it is an epistle that teaches practical Christianity. Nevertheless, some scholars are of the opinion that 1 Pet. 3:19 is one of the hardest texts in the entire New Testament corpus (keown, 1986). It seems to promote the notion of life after death, or the immortality of the soul, and also the doctrine of second chance. So scholars over the years have wrestled with the text so as to decipher what Peter means by the spirits in prison. However, it is the objective of this study to ascertain the meaning of the phrase; "the spirits in prison", hence to nullify the claim that this text can be used in supporting the fore mentioned teachings in Christendom.

\subsection{Key Issues in Peter}

The first epistle of Peter does not provide its readers with the time in which it was written (Barnes, 1975). Nevertheless, it seems the epistle was written at a time when the church suffered from external persecution, i.e., from the Roman government. For that cause, two broad persecutions arc suggested by scholars in association with 1 Peter. First, the Neronian persecution, and then the Dominitian persecution. "If it is thought that the persecution was that of Dominitian, it must have been written near the end of the first century"(Downey, 1929). Further, scholars suggest that First Peter was written in the year 63 A.D., others suggest that it was 64 or 65 A.D. In fact, some even go ahead to postulate 58, or 60, or 61 A.D. for the dating of First Peter (Barnes, 1975). Be that as it may, "the situation revealed in the letter may be as early as the time of Nero (64 A.D.)". The letter does not tell us the date of writing, but it does not fail in informing its readers about the author. The first epistle of Peter is generally attributed to the bearer of that letter, "Peter an apostle of Jesus Christ" (1 Pet. 1:1). And without much debate, this Peter who wrote the epistle that bears his name, is the same person in the Gospel narratives and also featured in the Acts of the Apostles. It is said that Peter wrote his first epistle in Rome after Paul's imprisonment and his journey to Spain (Lensky, 1956).

Nevertheless, due to the fine Greek style that is found in First Peter, scholars are suggesting that he could not have been the author of this epistle. In other words, they find it hard to accept that Peter, "the Galilean fisherman becoming such a master of a language which was not his mother tongue"(Downey, 1929). However, it is vital to mention that: "Galilee was bilingual. All the New Testament writers that came from Galilee could speak and write Greek"(Lenski, 1956). It is very possible, therefore, that Peter, being a Galilean, could equally speak and write in the Greek language no matter how rough it may be. But seeing that his first epistle projects such a mastery of the language, we have no difficulty in consenting to the fact that First Peter was written through the agency of Silvanus(Hastings, 1898), himself a Greek or better still a Hellenistic Jew( Downey,1929).

\subsection{Audience of the Epistle}

Peter, in his introduction, also included his recipients: "To the pilgrims of the Dispersion in Pontus, Galatia, 
Cappadocia, Asia, and Bithynia" (1 Pet. 1: 1b NKJV). Further, some early church fathers such as Eusebius and Jerome claim that these "strangers" or "pilgrims" were "native-born Jews, who had been converted to the Christian faith". Other scholars opine that they were "all of Gentile origin". In fact, some claim that "they were Gentiles by birth, but had been Jewish proselytes, or 'proselytes of the gate', and had been converted to Christianity" (Barnes, 1975). Besides, Maclaren (1984) claims that the pilgrims in those Gentile nations mentioned in 1 Pet. 1: lb, "may refer to the scattered Jewish people". Barnes adds that they were "not Jews in general, but those of the ten tribes who had wandered from Babylon and the adjacent regions into Asia Minor". The last postulation however, is that: the people whom the Apostle Peter addressed were basically Christians. It is possible they were converts from both Judaism and Heathenism, but Peter simply employed a language common to the Jews in his opening statements (Barners, 1975). In sum, Peter was writing to Gentile congregations which had a minority of Jews in their membership.

\subsection{Historical Background}

The infant church after Pentecost indeed suffered persecution, even from the hands of the Sanhedrin (Bigg, 1975), which consequently led to the death of Stephen and the spread of the Gospel (Acts 3-4, 7-8). In Acts we also see that the church suffered persecution through Saul before his conversion (Acts 9). More so, it seems that the church was not just persecuted by the Jewish leaders, but the Roman leaders were involved. As a matter of fact, Jews in Rome were ordered by Emperor Claudius to evacuate the city (Acts 18:2).

Moreover, that the Christians were scattered throughout the cities of Asia Minor which Peter mentions in 1 Pet. 1: 1b, is enough reason for us to infer that they did go through severe persecution. Besides, it is also possible that it was even the persecution that caused them to scatter abroad. To add to that, if the persecution led to the loss of life, in terms of martyrdom, Peter would have probably mentioned. Another possible view is that, there was religious discrimination by the Gentile government towards the Christian community of faith; also the Christian servants were oppressed by their masters (1 Pet 2:13-14, 16-19).

Nevertheless, scholars argue back and forth regarding the scope of the persecution (Elliot, 2000). Now, whether this persecution was world-wide or not, Peter's first epistle does not answer that. But one thing we do know is that the Christians were treated unjustly (1 Pet. 2:12). However, from the tone of Peter's first epistle, we may deduce that what led to the writing was the oppression which the Christian church was passing through. However, Peter describes their condition (persecution) as "the trial of your faith" (1 Pet. 1: 7).

First of all, Peter wrote his first epistle to indoctrinate the "newly-converted Jews" regarding the Christian religion (Church and Hist, 1972). It is postulated that the churches which Peter wrote to were founded not by Peter but Paul during his second missionary journey (see Acts 16: 6-7). Consequently, Paul and Peter met in Rome (64 A.D.); shortly after Paul would be away to Spain: which was why "he asked Peter to keep an eye on his great fields in Asia"(Lenski, 1956). In writing therefore, Peter began with their calling and conversion into the family of God. Secondly, Church, (1939) opines that Peter wrote his epistle to instruct the converts to live a holy life (1 Pet. 1: 15-16). Thence, Peter was admonishing them to deny worldliness and carnal affections, that with their whole soul they may desire "the celestial kingdom of Christ". The third purpose for Peter's writing is to prepare their hearts for suffering in the world for the sake of their faith. Seeing these were new converts into the Christian fold, the persecution could have reduced them in number (not necessarily in terms of death) back to the world they were called out from. Therefore, Peter wrote to fortify and strengthen them in a time of "special affliction"(Downey, 1929); and to establish them firmly in Christ. Peter himself demonstrated this unwavering faith when he held on to his testimony even to the point of death. "Shortly after Peter had written this letter he suffered martyrdom".

\section{Exegetical and Theological Study of 1 Pet. 3:19}

This section carries uses the historic-grammatical method of exegesis in studying the passage under question placing it in its right context. In doing that, we would employ the basic steps of doing exegesis: Literary unit (Immediate and Larger context), Genre, Textual Analysis, Translation, Structure and Interpretation/ Theology. More so, we would place the text in its historical context so as to garner what it meant to the author (Peter) as well as the immediate audience, "the strangers scattered" (1 Pet. 1: lb).

Literary Unit

The literary unit is the contextual framework which strategically houses the passage under discussion. Hence, this literary unit places the text (1 Pet. 3: 19) within its right context, considering the preceding issues as well as the matters that follow up. Usually, the literary unit is divided in two: Larger and Immediate Context.

\subsection{Larger Context}

The larger context contains blocks of various yet interconnected stories (in terms of a narrative) and ideas through a chapter or segment. While we keep that in mind, we proceed to identify the larger context of 1 Pet. 3:19. Further, the larger context of 1 Pet. 3: 19 is: 1 Pet. 3: 13-4: 7. Actually, Peter introduces the theme of suffering (or persecution as the case may be) in 1 Pet. 3: 13, then he ends that theme with an admonition 
regarding their preparation for the Parousia in 1 Pet. 4: 7.

\subsection{Immediate Context}

The immediate context of 1 Pet. 3: 19 is 1 Pet. 3:18-22; within these verses Peter uses the example of Jesus' suffering in connection with what the then Christians were passing through. Thus 1 Pet. 3:19 strategically falls within the literary framework of 1 Pet. 3:18-22, seeing then that the subject of discussion is Christ.

\subsection{Genre}

First Peter's genre is epistolary. However, the genre of 1 Pet. 3: 18-22 is at first multiple in nature; although it is primarily a prose, it could be subdivided into metaphor (1 Pet. 3: 19), and even history (1 Pet. 20).

\subsection{Textual Analysis}

This segment carries out an analytical study of the immediate context (1 Pet. 3:18-22), to harvest any variant readings within the text. 3.18 peri amartion epathen $\{\mathrm{B}\}$ The bewildering diversity of readings can be listed in connection with the variation involving the accompanying verb. Followed by epathen the variants are: (a) B K P 0490560142 326*330 45118772127 Byz Lect Ps-Oecumenius. (b) 326C . (c) 22412423253374604892432. Followed by the variants are: (d) A 2064294411241 arm. (e) C $C^{2 \text { vid }} 3388322323436614630$ (f) 94517391881 2412 copbo eth Didymus. (g) C $\mathrm{C}^{* \text { vid }} 56292298$ it $^{65}$ syr $^{\mathrm{p}}$ cop $^{\text {sa }}$ Cyprian. (h) Didymus.

While acknowledging the difficulty of ascertaining the original text, a majority of the Committee preferred the reading peri amartion epathen because (a) this verb, which is a favorite of the author (it occurs elsewhere in 1 Peter eleven times), carries on the thought of ver. 17, whereas apothneskeiv (which occurs nowhere else in the epistle) abruptly introduces a new idea; (b) in view of the presence of the expression peri amartion scribes would be more likely to substitute apethanen for epathen than vice versa; and (c) the readings with hemon or humon (which in later Greek had the same pronunciation) are natural and, indeed, expected scribal expansions.

\section{$\mathbf{3 . 1 8}\{\mathrm{C}\}$ humas}

The Committee was inclined to prefer humas accidentally omits the pronoun) ACK81 $6141739 \mathrm{vg}$ syr $^{\text {hmg }}$ cop $^{\text {sarbo }}$ Clement), because copyists would have been more likely to alter the second person to the first person (as more inclusive) than vice versa.

3.19 en o kai

Several scholars have advocated the conjectural emendation that introduces the subject "Enoch" Instead of improving the intelligibility of the passage (as a conjectured reading ought to do), the word Enoch breaks the continuity of the argument by introducing an abrupt and unexpected change of subject from that of ver. 18 .

\subsection{Ho}

Despite the difficulty of construing $h o$, the Committee felt obliged to accept it as the text, $(a)$ because it is strongly and widely supported by -- ${ }^{\mathrm{c}}$ A B C K P --- $33816141739{\text { Byz } \text { it }^{65} \text { vg arm Cyprian Origen }}^{\text {lat }}$ al, and (b) because the other readings are obvious ameliorations of the difficulty, some witnesses having omitted the word, and others having substituted for it either $O(692062162416301518)$ or ---- (cop ${ }^{\text {bo vid }}$ Augustine $\left.^{\text {vld }}\right)$.

\subsection{Theo}

After Theo most manuscripts of the Vulgate insert deglutiens mortem ut vitae aeternae haeredes efficeremur ("swallowing up death that we might be made heirs of eternal life"). As is suggested by the use of the present participle deglutiens in the sense of the past tense, it is probable that the addition is a translation of a Greek gloss, which, according to Harnack's reconstruction, may have read katapion (tov) thanaton, hin zoes aioniou kleronomoi genetomen

(BibleWorks $\sim$ c: $\mid$ program files (x86) \bible works $7 \backslash$ init $\backslash 700 . s w c]$.

\section{Translation}

Based on the textual analysis above, there is obviously nothing that warrants another translation of the passage under discussion. However, for the sake of our study, we shall provide a working translation of the text (1 Pet. 3: 18-22). "Since Christ also underwent suffering once and for all in reference to sin, the just for the unjust, so that he may bring us to God; after dying as a mortal, he was brought back to life by the Holy Spirit: through whom he carried out the preaching unto the people living in darkness: who were at some time disobedient when God eagerly waited with forbearance in the days of Noah, while he was in the process of constructing the ark, in which only few, even eight persons were delivered through the flood. Now this water of the flood stands as an antitype for baptism which saves $u s$ - not the outward washing of the body but a conscientious seeking of God- through the resurrection of Jesus Christ; who has ascended into heaven, and is on the right hand of God, having angels and authorities and powers all subject to him".

\subsection{Interpretation of 1 Pet. 3:19}

In carrying out the interpretation, we would pay a keen attention to two crucial points: the person who did the preaching, and the time which the preaching was done. Once these points are clarified, then the expression "the 
spirits in prison" would also be demystified.

\subsection{The Suffering of Christ}

Peter inserts in the middle of his discussion the theme of Jesus' suffering to inform the Gentile converts that their unjust suffering (for the name of Christ) is not peculiar to them. But even this Christ whom they followed did suffer once and for all as a sinner. Peter used this word to suggest the once and for all sacrifice of Jesus on the Cross which brought to end the Jewish sacrificial system in the temples for sin offering. Though Christ was sinless and faultless, yet He was treated as though He committed sin: that sinners should be set free (1 Pet. 2:21-25).

Further, Peter inserts as the purpose of Jesus' suffering the justification of sinners: "just in place of unjust" (1 Pet. 3: 18b). In essence, the righteousness of Christ covers for the unrighteousness of the sinner: which then makes the sinner appear as if he had never sinned, hence they become reconciled unto God. Thus Christ's suffering offered the restoration of a broken relationship between Divinity and humanity breached by iniquity. Beyond that, the suffering also caused the death of Christ. But to give the Gentile Christians hope, Peter quickly adds the concept of the resurrection; that Christ, though he died because of suffering and sin, was brought back to life through the aid of the Holy Spirit.

\subsection{The Agency of the Holy Spirit}

The Holy Spirit, in the context of Peter's discussion, performs a dual function. First, the raising of Jesus Christ from the dead; second, through the Holy Spirit, the spirits in prison" were preached to (1 Pet. 3: 19). What Peter meant was, the same Power (of the Holy Spirit) which brought Christ back to life was the Power which accompanied the preaching of the gospel (cf. I Pet. 1: 12).

\section{The Spirits in Prison}

It has already been established that it was the Holy Spirit which aided in the preaching. Nevertheless, the crux of the discussion centres on the audience of the Preacher; the spirits in prison. There are different shades of interpretation regarding that expression. Scholars like Elliot are of the opinion that "the spirits in prison" were the fallen angels that later became demons, having Azaz'el (Elliot, 2000) as their leader. These demons were at the forefront of the rebellion of the Antediluvians. Others think that the spirits in prison were those that died during the flood, hence they are disembodied souls. Thus at Jesus' death, he went to preach (repentance and forgiveness) unto them.

Starting from the last author, Mueller, who claims that "the spirits in prison" were disembodied souls which Christ preached to at His death; we say it cannot be so. For it goes contrary to the flow and structure of the sentence. In 1 Pet. 3: 18, we learn that Jesus died due to suffering for sinners; on the other hand he was raised from the dead through the Holy Spirit. Therefore, the Christ which Peter refers to in verse 19 cannot be Christ at death, but the Living Christ. Consequently, the preaching was not done at His death. And if Mueller claims the preaching was done at Jesus' death unto the souls of the dead, and we've established the fact that Christ didn't do the preaching at death: then it also counters Mueller's second argument that the spirits in prison were the souls of the dead.

Elliot also claims that the spirits in prison were fallen angels and/or demons. To address Elliot's point, we need to decipher the genre of the expression if is it literal or symbolic? If the former, it is imperative to note that spirits cannot be confined to prison walls. In fact, we cannot treat spirits as literal, then the prison as symbolic: for the two are expressions. Thence, the expression does not always mean "prison" or "guard"; it also means the period of the night between sunset and sunrise divided into four watches of three hours each (Mt 14: 25; 24: 43; Mk 6: 48; Lk 12: 38; Mk 13:35), or the hour of darkness. Therefore, it also means night or darkness. So now the problem remains which takes different shades of meaning in the New Testament, meaning spirit or life-giving breath (Matt. 27: 50), the immaterial part of man (1 Cor. 5: 3; Col. 2: 5; 1 Thess. 5: 23; Heb. 4: 12), or one's very self (Rom. 8: 16; Phil. 4: 23). Deducing from the last translation one's very self, is related to individuals or persons. Thus we can now translate "as people in darkness". The darkness being characterized by disobedience (1 Pet. $3: 20 \mathrm{a})$.

\subsection{The Time of the Preaching}

Peter does not leave his readers wandering as to when the preaching took place. In the very next verse (1 Pet. 3:20), he provides clues and hints that enlighten our perspective on the spirits in prison. Apart from the fact that they were living in unbelief, Peter mentions also that: God waited on them eagerly with much endurance that they may turn away from their evil ways. Next, we learn that the period when God demonstrated His loving-patience to the disobedient or spirits in prison "in the days of Noah". This nails the argument that the preaching was done at the time of Jesus' death: for the text makes it evidently clear that it was during the time of Noah, as in the days before the flood. Therefore, the spirits in prison (people in darkness) were not disembodied souls who died as a result of the flood, but living people before the flood (Gen. 6:1-13; Matt.24:37-39; Luke 17:26-27). Thus when the people continually rebelled against God, He then instructed Noah to build an ark as a means of salvation for his family 
and the various species of living things (Gen. 6:14-7:24). As a matter of fact, Peter makes it explicitly clear that the preaching was done; that is "while [Noah] was still constructing the ark" (1 Pet. 3: 20c). Out of the multitude of the people in the generation of Noah, only eight souls were saved by water because they believed in the preaching of the forth coming destruction of the world through the flood (Gen. 7:1,7; 1 Pet 3:20d; 2 Pet. 3:6).

\subsection{Theological relevance of 1 Pet.3:19}

First of all, 1 Pet. 3:19 in the context of the entire epistle presents us with the theology of suffering and justification. Suffering is intricately part of the Christian experience, aimed at purifying and establishing believers firmly in the faith which they profess. In fact, when Christians suffer, they should consider such as a moment of testing. By the way, even Christ Himself suffered as a sinner for the justification of our sins hence leaving us an example that we may follow His steps (1 Pet. 2: 21-22). So to us Christians today, in the course of our suffering, we should have Christ as our model and consolation.

Second, the text also provides the theology of death and resurrection. Suffering may lead to death, but death is not the end of the Christian who died believing in Christ. So this eternal hope of rising from the dead at the resurrection should strengthen us Christians to hold on to our faith to the very end. In fact, it will serve as a grand testimony unto those outside the Christian community of faith.

Third, the passage hints on the theology of sin. To any Christian who disregards the voice of God through His servants and apostles, such is counted as disobedience. And disobedience bounds the heart of man to enormous evil and immorality, making such bound to their lustful passions as if they were in prison. Christians should walk in the light God has provided in His Word which alone can keep us from stumbling and keep us within the confines of righteousness.

Fourth, the passage presents the theology of Grace. God does not immediately pass judgment on any generation of people that is rebellious; He rather gives sinners the chance for repentance so that when He acts finally $\mathrm{He}$ shall be justified. More so, Christians today should not count the seeming delay in the judgment of God (as in the Parousia) as slackness, but He is simply demonstrating forbearance towards us as He did in the time of Noah so that no one would perish (1 Pet. 3: 20; 2 Pet. 3: 9)

Fifth, the text emphasizes the theology of Baptism. Baptism is essential for our salvation. It is a sign of death to our old manner of living as well as a mark of new life in Christ (1 Pet. 3: 21; Rom. 6: 1-7). Thence, Christians who are baptized should also forfeit their sinfulness and walk in righteousness, and not taking baptism to mean a mere rite or tradition.

Finally, the text also provides the theology of Ascension. Peter didn't only mention the theme of suffering, death and resurrection; but emphasized the glorification of Christ after his ascension into heaven (1 Pet. 3:22). Therefore within the context of 1 Pet. 3:18-22, Peter discusses the subject of salvation, and the reward which Christians shall receive should they endure to the very end.

\section{Conclusion}

From the findings of this research, these are the following conclusions: First, Peter wrote his epistle (through Silvanus) in a time when the Gentile Christians were passing through trials and temptations; hence his aim was to comfort and fortify them regarding the Christian faith which they adhered to. Second, we conclude that the preaching to the spirits in prison was done through the agency of the Holy Spirit. Third, we conclude that the spirits in prison were not demons nor disembodied souls but the people living in the time of Noah before the flood. Fourth, we conclude that in the actual sense it wasn't Christ that did the preaching but Noah, who forewarned the people of his time. Finally, the preaching was not done at Jesus' death but (by Noah) in the days before the destruction of the world through the flood, while Noah was still preparing the ark.

\section{References}

Barnes, A. (1975). Notes on the New Testament: James-Jude: Explanatory and Practical. Grand Rapids, MI: Baker Book House.

Bible Works [c: :program files (x86) \bible works 7 7 init $\backslash 700$. swc].

Bigg, C. "Critical and Exegetical Commentary on the Epistles of St. Peter and St.

Jude" in Driver, S.R., Plummer, A., Briggs, C.A. eds., (1975). The International Critical Commentary. Edinburg: T\&T Clark.

Church, L.F \& Hist, F.R. (1972). The Matthew Henry Commentary. Grand Rapids, MI: Zondervan Publishing House.

Downey, D.G. (1929). The Abingdon Bible Commentary. Nashville: Abingdon Press.

Elliot, J.H. (2000). 1 Peter: A New Translation with Introduction and Commentary, New York: Doubleday.

Hastings, J. (1898). A Dictionary of the Bible: Dealing with its Language, Literature, and Contents, including the Biblical Theology Vol. 4. Edinburg: T\&T Clark.

Keown, G.L. (1986). "SPIRITS IN PRISON" in Bromiley, G.W. The International Standard Bible Encyclopedia. 
Grand Rapids, MI: William B. Eerdmans Publishing Company. 1986.

Lenski, R.C.H. (1956). The Interpretation of the Epistle of St. Peter, St. John and St. Jude. Columbus, OH: The Wartburg Press.

Maclaren, A. (1984) Expositions of the Holy Scripture: First and Second Peter and First John. Grand Rapids, MI: Baker Book House.

Metzger, B.M. (2002). A Textual Commentary on the Greek New Testament. Stuttgart: German Bible Society.

Mueller, E. J Pet. 3:18-22. Biblical Research Institute General Conference of Seventh-day Adventists ${ }^{\circledR}$.

Torrance, D.W. \& Torrance, T.F. (1963). Calvin's Commentaries: The Epistle of Paul the Apostle to the Hebrews and the First and Second Epistles of St. Peter. Edinburg: Oliver \& Boyd. 